\title{
Black Carbon Aerosol in the Industrial City of Xuzhou, China: Temporal Characteristics and Source Appointment
}

\author{
Wei Chen ${ }^{1}$, Huimin $\operatorname{Tian}^{1}$, Kai Qin ${ }^{2 *}$ \\ ${ }^{1}$ College of Geoscience and Surveying Engineering, China University of Mining and Technology, Beijing 100083, China \\ ${ }^{2}$ School of Environmental Science and Spatial Informatics, China University of Mining and Technology, Xuzhou 221116, \\ China
}

\begin{abstract}
Black carbon (BC) aerosol in urban environments potentially affects the local environment, the regional climate cycle, and even human health. A two-year field measurement (May 2014 to July 2016) of BC and particulate matter in Xuzhou, a large industrial city and the economic center of Huaihai Economic Zone in central China, was conducted. The average annual concentrations of $\mathrm{BC}, \mathrm{PM}_{1.0}, \mathrm{PM}_{2.5}$, and $\mathrm{PM}_{10}$ were $2.44 \mu \mathrm{g} \mathrm{m}^{-3}, 56.6 \mu \mathrm{g} \mathrm{m}^{-3}, 61.8 \mu \mathrm{g} \mathrm{m} \mathrm{m}^{-3}$, and $75.8 \mu \mathrm{g} \mathrm{m} \mathrm{m}^{-3}$, respectively. The highest daily average for the $\mathrm{BC}$ concentrations was $11.6 \mu \mathrm{g} \mathrm{m}^{-3}$, and more than $10 \%$ of the hourly $\mathrm{BC}$ measurements had concentrations above $5 \mu \mathrm{g} \mathrm{m} \mathrm{m}^{-3}$. All of the $\mathrm{BC}$ and PM concentrations displayed two diurnal peaks (during rush hours in the morning and in the evening) and one valley (in the afternoon). The overall BC concentrations, and the $\mathrm{BC}$ fractions in the PM were higher in winter and spring, whereas the overall PM concentrations were higher in winter and autumn. The backward trajectory analysis indicated that most of the high BC concentrations in Xuzhou were associated with north and northwest winds, and the potential source contribution function (PSCF) model proved that the provinces of central China were the most likely source regions. Our findings can be used to set appropriate atmospheric pollution control measures for these central provinces and to increase the accuracy of air quality forecasting.
\end{abstract}

Keywords: Black Carbon; Particulate Matter; $\mathrm{PM}_{2.5}$; Air Pollution.

\section{INTRODUCTION}

Aerosol is an important component in the atmospheric environment that affects the radiative balance of the earth (Kuang et al., 2015; Sun et al., 2018), human health (Janssen et al., 2013), and climate change (Xin et al., 2016; Che et $a l ., 2018)$. The particle size of aerosol particles can range from several nanometers to hundreds of micrometers (Qin et al., 2018), with extremely heterogeneous spatial distribution. The sources of aerosol can be divided into two categories: natural (oceanic, dust, etc.) and anthropogenic (Knobelspiesse et al., 2011). Among the anthropogenic sources, black carbon (BC, sometimes denoted as "soot") is mainly formed during the incomplete combustion of fossil fuels (coal, etc.), biofuels, and biomass (Chen et al., 2016). Due to the rapid increase in the number of vehicles and the usage of coal as an energy source, China has become the largest producer of $\mathrm{BC}$ emissions, contributing approximately $17 \%$ of total global BC emissions (Chameides and Bergin, 2002).

\footnotetext{
* Corresponding author.

Tel.: +86-15950663287

E-mail address: qinkai@cumt.edu.cn
}

Particulate matter, on the other hand, has been deemed as the major reason for the air quality deterioration in the region of northern China and has become a serious health burden for urban residents (Song et al., 2017; Guo et al., 2018).

Particulate matters $\left(\mathrm{PM}_{1.0}, \mathrm{PM}_{2.5}\right.$, and $\left.\mathrm{PM}_{10}\right)$ have been paid great attention by many researchers considering the serious haze-fog events in the region of northern China (Zhang et al., 2013). The implementation of new National Ambient Air Quality Standards (NAAQS-2012, GB30952012) has required major cities in China to monitor $\mathrm{PM}_{2.5}$, $\mathrm{PM}_{10}, \mathrm{SO}_{2}, \mathrm{NO}_{2}, \mathrm{CO}$, and $\mathrm{O}_{3}$ at 1-hour intervals, providing ample data sources for atmospheric environment research. With these monitoring data, average $\mathrm{PM}_{2.5}$ concentrations in different cities have been calculated: $83 \mu \mathrm{g} \mathrm{m}^{-3}$ in Beijing (Batterman et al., 2016), $101.6 \mu \mathrm{g} \mathrm{m}^{-3}$ in Baoding (Li et al., 2017), $72.3 \mu \mathrm{g} \mathrm{m}^{-3}$ in Chengdu, $39.5 \mu \mathrm{g} \mathrm{m}^{-3}$ in Guangzhou, $50.8 \mu \mathrm{g} \mathrm{m}^{-3}$ in Shanghai, and $79.2 \mu \mathrm{g} \mathrm{m}^{-3}$ in Shenyang (Fontes et al., 2017). Four regions have been affected the most by fine particulate matters: the BeijingTianjin-Hebei region, the Yangtze River Delta region, the Pearl River Delta region, and the Sichuan Basin (Chai et al., 2014; Wang et al., 2014).

Although the $\mathrm{BC}$ concentration in the atmosphere is relatively low, it could strongly absorb incident solar 
radiation, forming strong positive radiative forcing (Hansen and Nazarenko, 2004): The global average radiative forcing of anthropogenic BC aerosol is approximately $0.71 \mathrm{~W} \mathrm{~m}^{-2}$, suggesting that $\mathrm{BC}$ may be the second most important component of global warming, following only $\mathrm{CO}_{2}$ (Jacobson, 2001; Bond et al., 2013). Freshly emitted BC particles are aggregated by hundreds of monomers with fractal structures and later tend to be mixed with other atmospheric components, such as organics, dust, sulfate, and water (Cheng et al., 2015a), which is known as the aging process of black carbon. During the aging process, the mixing state and morphology of black carbon aerosol all have significant changes. The change from external mixing to internal mixing of black carbon and other aerosols will increase the absorbing cross section of aerosol particles, altering the single scattering albedo and asymmetry factor (Wu et al., 2016). In addition, during the aging process of black carbon aerosols, they can absorb sulfate, nitrate, and water vapor, becoming the spot for chemical reactions, playing an important role in the formation of secondary aerosol particles (Zhang et al., 2016). The broadband absorbing characteristics make black carbon aerosol strongly affect the earth-atmosphere systems. A climate model simulation suggested that absorbing aerosol could inhibit the formation of a cloud if present in the cloud, or increase the formation of a cloud if below the cloud (Koch and Del Genio, 2010). Furthermore, absorbing aerosol could increase the extent of a tropical area (Kovilakam and Mahajan, 2015), affecting long-term global climate (Li et al., 2015b) and accelerating snow melting (Yang et al., 2015).

Many field observations have been performed to understand the concentration variations, chemical and microphysical properties, and optical properties of black carbon aerosols in China. The annual measurement of particulate matter in Fudan University suggested the annual average $\mathrm{BC}$ concentration in Shanghai was approximately $3.0 \mu \mathrm{g} \mathrm{m}^{-3}$ (Wang et al., 2016). A nine-year measurement by the China University of Geosciences (Beijing) suggested the average $\mathrm{BC}$ concentration from 2005 to 2013 was $4.3 \mu \mathrm{g} \mathrm{m}^{-3}$ (Chen et al., 2016). Another five-year measurement suggested the $\mathrm{BC}$ concentration in Beijing from 2010 to 2014 was $3.67 \mu \mathrm{g} \mathrm{m}^{-3}$ (Liu et al., 2016). Despite the inter-annual variations, there were obvious seasonal patterns of $\mathrm{BC}$ concentrations in Beijing: The winter seasons had the highest BC concentrations, followed by the autumn, summer, and spring ( $\mathrm{Xu}$ et al., 2015). Zhang et al. (2015b) conducted a one-year observation of BC in Hefei from June 2012 to May 2013, finding that the annual average $\mathrm{BC}$ concentration in Hefei was $3.5 \mu \mathrm{g} \mathrm{m}^{-3}$ with seasonal variations: winter $>$ autumn $>$ spring $>$ summer. Li et al. (2015a) collected approximately 80 days of samples (approximately 20 per season) in Nanjing from November 2011 to 2014 and found that the average BC concentration was approximately $5.3 \mu \mathrm{g} \mathrm{m}^{-3}$. Qin et al. (2017) carried out a campaign for investigating BC and aerosol optical properties under haze conditions over Shijiazhuang in the winter from late 2013 to early 2014, displaying extremely high records with a larger ratio of BC to $\mathrm{PM}_{2.5}(12.11 \%$ on average $)$. $\mathrm{BC}$ concentrations in all four seasons were well correlated with OC concentrations, suggesting that it was highly possible that $\mathrm{OC}$ and EC in Nanjing were attributable to common sources. Although $\mathrm{BC}$ only contributed slightly to the total $\mathrm{PM}_{2.5}$ concentration, it could have heated the upper planetary boundary layer (PBL) and depressed the development of PBL, thus enhancing the haze pollution episodes (Ding et al., 2016). Peng et al. (2016) performed experiments in Beijing and Houston and found that BC could age heavily and greatly contribute to large positive radiative forcing. Widely carried out urban $\mathrm{BC}$ concentration measurements all suggested heavy anthropogenic $\mathrm{BC}$ pollutions in China. However, most of this research focused on megacities, such as Beijing or Shanghai, or regional centers, such as Hefei or Nanjing. For Xuzhou, a large industrial city in eastern China with large amounts of coal production and combustion, real-time and long-term measurement of BC is still limited.

Here, with two-year surface measurements of $\mathrm{BC}$ concentrations in Xuzhou at the China University of Mining and Technology from May 2014 to July 2016, BC variation of this city is presented. The additional particulate matter measurements of $\mathrm{PM}_{1.0}, \mathrm{PM}_{2.5}$, and $\mathrm{PM}_{10}$ were also collected to investigate the $\mathrm{BC}$ concentration under different particulate matter pollution episodes. The main objectives of this study were to 1) investigate the temporal variation patterns of $\mathrm{BC}$ in Xuzhou, 2) determine the relationship between $\mathrm{BC}$ and particulate matters, and 3) find the potential source of BC in Xuzhou.

\section{STUDY AREA AND DATA MEASUREMENTS}

\section{Study Area}

Xuzhou $\left(33^{\circ} 43^{\prime} \mathrm{N}-34^{\circ} 58^{\prime} \mathrm{N}, 116^{\circ} 22^{\prime} \mathrm{E}-118^{\circ} 40^{\prime} \mathrm{E}\right)$ is a large industrial city in northwestern Jiangsu Province in eastern China, at the junction of Jiangsu, Shandong, Henan, and Anhui Provinces. Moreover, it is the economic center of the Huaihai Economic Zone of China, and an important transportation hub in eastern China. Huaihai Economic Zone has an area of 17.8 million $\mathrm{km}^{2}$, connecting Beijing-Tianjin-Hebei Economic Zone in the north, Coastal Economic Belt in the east, Yangtze River Delta Economic Belt in the south, and Central Plains Economic Region in the west. Over 1.3 billion residents are now living in the Huaihai Economic Zone with a total GDP of more than 4.9 trillion yuan. As the economic center city of Huaihai Economic Zone, Xuzhou has experienced fast economic development over the past decades. At the same time, the air quality in Xuzhou has deteriorated with frequent haze-fog events. The heavy atmospheric pollution in Xuzhou has become an important issue for both local residents and city image. Unfortunately, few researches concerning the atmospheric pollution, especially about BC, have been done here.

At present, Xuzhou has over 8.6 million inhabitants and an area of $11,258 \mathrm{~km}^{2}$. As a typical industrial city with coal as major energy source, there are many coal mines and industrial parks in Xuzhou. The industrial parks are mainly located to the north of the urban area in the upwind direction during the seasons that require heating. The city 
of Xuzhou is located in a basin region with small hills around it, making it easily polluted when the meteorological dispersion conditions are poor. Furthermore, as shown in Fig. 1, Xuzhou is located northwest of the Yangtze River Delta region and southeast of the Beijing-Tianjin-Hebei region, making it easily affected by regional transported pollution from these two regions (Qin et al., 2016).

\section{Measurements}

Black carbon concentration was continuously measured by a 7-wavelength $(370,470,520,590660,880$, and $950 \mathrm{~nm})$ aethalometer (Model AE-42, Magee Scientific, USA). The aethalometer works under the theory that the attenuation of light transmitted through a fibrous filter is linearly proportional to the amount of $\mathrm{BC}$ in the filter deposit. The optical attenuation of the light (ATN) is defined as Eq. (1):

$\mathrm{ATN}=100 \times \ln \left(\mathrm{I}_{0} / \mathrm{I}\right)$

where $I_{0}$ is the intensity of light transmitted through the original filter or the blank part of the filter, and I is the light intensity transmitted through the part of the filter with $\mathrm{BC}$ deposit. The absorption of light by $\mathrm{BC}$ is inversely proportional to the wavelength of the light used, and the ATN of a specific wavelength could be written as a function of the mass deposit of BC in Eq. (2):

$\mathrm{ATN}_{\lambda}=\sigma_{\lambda} \times \mathrm{M}_{\mathrm{BC}}$

where $\mathbf{M}_{B C}$ is the mass deposit of black carbon, and $\sigma_{\lambda}$ is the mass absorption cross section of black carbon in wavelength $\lambda$. The increase of ATN between two continuous measurements is proportional to the increase of the $\mathrm{BC}$ mass deposit $\Delta \mathrm{M}_{B C}$ as Eq. (3):

$\Delta \mathrm{ATN}_{\lambda}=\mathrm{ATN}_{\mathrm{i}}-\mathrm{ATN}_{\mathrm{i}-1}=\sigma_{\lambda} \times \Delta \mathrm{M}_{\mathrm{BC}}$

where $\triangle \mathrm{ATN}_{\lambda}$ is the increase of $\mathrm{ATN}, i$ is the measurement number, and $\triangle \mathrm{M}_{B C}$ is the increase of the $\mathrm{BC}$ mass deposit. Therefore, the average concentration of atmospheric environment between these two continuous measurements could be calculated as Eq. (4):

$\operatorname{Con}_{B C}=\frac{\Delta \mathrm{M}_{B C} \times S}{F \times \Delta t} \times 10^{9}=\frac{\left(\mathrm{ATN}_{i}-\mathrm{ATN}_{i-1}\right) \times S}{\sigma_{\lambda} \times F \times \Delta t} \times 10^{9}$

where $\operatorname{Con}_{B C}$ is the concentration of black carbon, $S$ is the area of the sample, $F$ is the flow rate, and $\Delta t$ is the sample interval.

According to Virkkula et al. (2007), the relationship between ATN change and BC concentration is not linear. The reasons include that the particles collected on the filter alter the internal reflection properties of the filter, hence making the relationship nonlinear. Therefore, the measured value from the aethalometer should be corrected before analysis. According to Virkkula et al. (2007), the corrected $\mathrm{BC}$ concentrations could be calculated by:

$$
\begin{aligned}
\operatorname{Con}_{B C_{-} \text {corrected }} & =\frac{\sigma_{a b s(\text { corrected })}}{\sigma_{\text {abs }(\text { uncorrected })}} \\
& =(1+k \cdot A T N) \text { Con }_{B C_{-} \text {uncorrected }}
\end{aligned}
$$

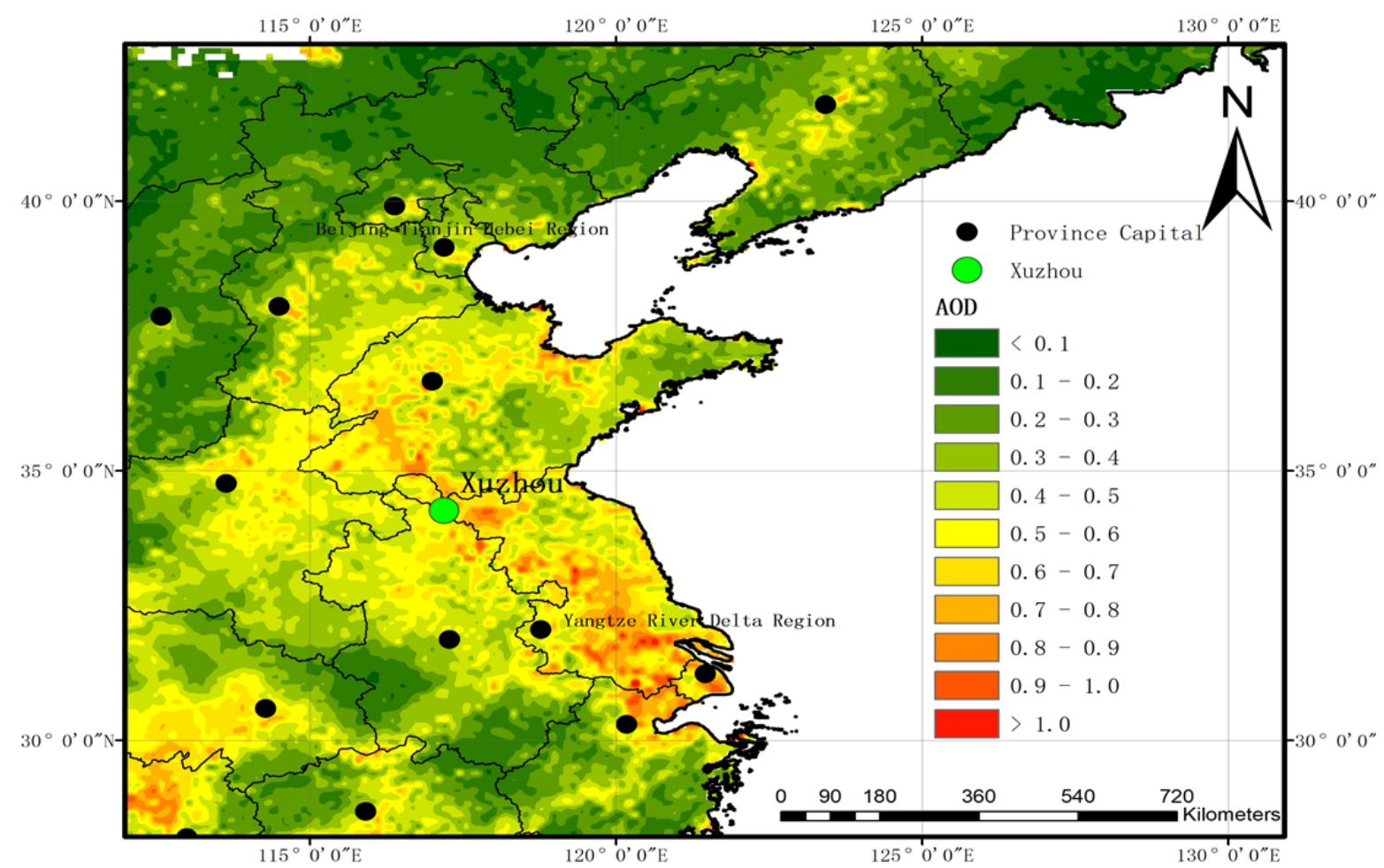

Fig. 1. Study area (Xuzhou) overlapped with annual averaged MODIS Aqua aerosol optical depth (AOD) in 2015. 
where $\sigma_{a b s(\text { corrected) }}$ and $\sigma_{a b s(\text { uncorrected) }}$ are the corrected absorption coefficient and uncorrected absorption coefficient, respectively. The coefficient $k$ in Eq. (5) could be calculated by the last measurement of a spot that is equal to the first measurement of the next spot when the spot change takes place as follows:

$$
\operatorname{Con}_{B C_{-} \text {corrected }\left(t_{i}, \text { last }\right)}=\mathrm{Con}_{B C_{-} \text {corrected }\left(t_{i+1}, \text { first }\right)}
$$

By combining Eqs. (5) and (6), the coefficient $k$ for the filter spot $i$ could be calculated by:

$$
\begin{aligned}
& d k_{i}=\left(\operatorname{Con}_{B C_{-} \text {uncorrected }\left(t_{i+1}, \text { first }\right)}-\operatorname{Con}_{B C_{-} \text {corrected }\left(t_{i}, \text { last }\right)}\right) / \\
& \left(A T N\left(t_{i}, \text { last }\right) \cdot \operatorname{Con}_{B C_{\text {corrected }\left(t_{i}, \text { last }\right)}}-A T N\left(t_{i+1}, \text { first }\right)\right. \\
& \left.\cdot \text { Con }_{B C_{-} \text {uncorrected }\left(t_{i+1}, \text { first }\right)}\right)
\end{aligned}
$$

By calculating the correct coefficient $k$ for the filter spot, the corrected BC concentrations could be obtained. During our experiments, the aethalometer was set to collect data at an interval of 5 minutes with a flow rate of $2 \mathrm{~L} \mathrm{~min}^{-1}$. The accuracy of BC measurements was approximately $0.1 \mu \mathrm{g} \mathrm{m}^{-3}$. In total, there were 699 daily data points collected for this study. In this study, the measurements taken at $880 \mathrm{~nm}$ were used as the standard channel for BC.

Particulate matter concentrations of $\mathrm{PM}_{1.0}, \mathrm{PM}_{2.5}$, and $\mathrm{PM}_{10}$ were measured by an EDM (Environmental Dust Monitor) 180 (GRIMM, Germany), which can classify particulate matter particles into 31 size bins at the range of
0.25 to $32 \mu \mathrm{m}$ with an accuracy of approximately $2 \%$. In addition, the meteorological data including wind speed, wind direction, and precipitation were also collected with a local meteorological station. This equipment (including the aethalometer and EDM 180) was all deployed at the same place on the rooftop of the building (about $20 \mathrm{~m}$ above ground) of the School of Environmental Science and Spatial Informatics, China University of Mining and Technology, Xuzhou, as part of the Mining Area Synergic Observation and Experiment Site. This site is surrounded by the major road in the north and east, and small mountains in the west, far away from heavy pollution sources. The measurements of $\mathrm{BC}$ and $\mathrm{PM}$ were simultaneous, ensuring that the $\mathrm{BC}$ and PM measurements were comparable.

\section{RESULTS}

\section{Temporal Variations of Black Carbon and Particulate Matters}

The overall daily average mass concentrations of $\mathrm{BC}$, $\mathrm{PM}_{1.0}, \mathrm{PM}_{2.5}$, and $\mathrm{PM}_{10}$ are shown in Fig. 2. For black carbon measurement, hourly means were calculated by averaging all 5-minute measurements within each hour. Only days with at least 16 hourly measurements were regarded as effective daily measurements to ensure representativeness. Therefore, 639 effective daily black carbon measurements were obtained. During the period from May 2014 to July 2016, daily BC maximum (minimum) was $11.6 \mu \mathrm{g} \mathrm{m}^{-3}$ $\left(0.07 \mu \mathrm{g} \mathrm{m}^{-3}\right)$, with an average concentration of $2.44 \mu \mathrm{g} \mathrm{m}^{-3}$. Some typical measurements of BC at other sites in China have been collected as shown in Table. 1 . It could be found that compared with the measurements of other big cities,

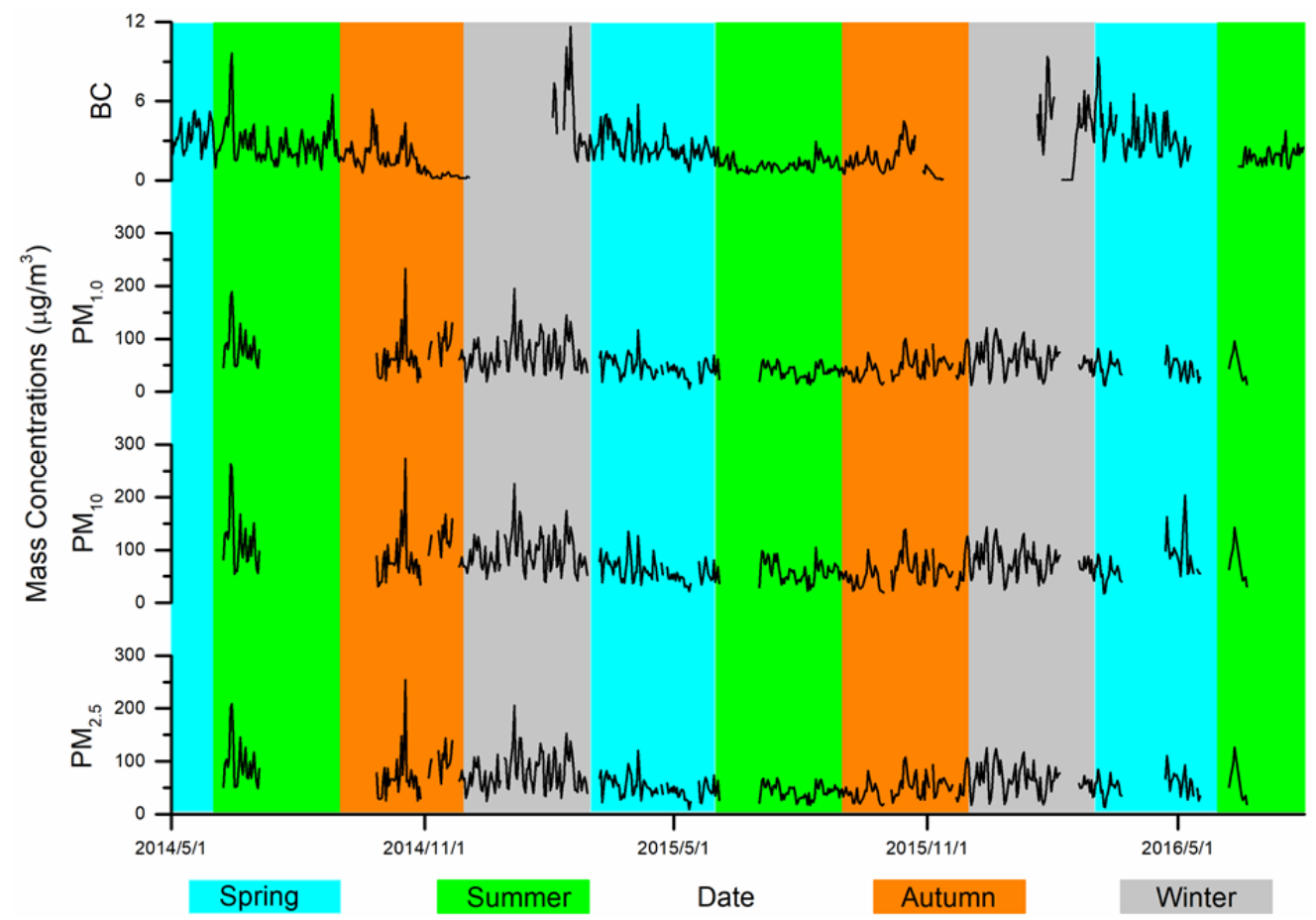

Fig. 2. Daily variations of $B C, P_{1.0}, P_{2.5}$, and $\mathrm{PM}_{10}$ in Xuzhou from May 2014 to July 2016. To ensure the representativeness of daily average, only daily measurements with more than 16 hourly means are selected. 
Table 1. Summary of BC measurements of typical sites in China.

\begin{tabular}{llll}
\hline Site & Average BC concentrations & Measurement Period & source \\
\hline Xuzhou & $2.24 \mu \mathrm{g} \mathrm{m}^{-3}$ & $2014-2016$ & This study \\
Shanghai & $3.0 \mu \mathrm{g} \mathrm{m}^{-3}$ & $2013-2014$ & (Wang et al., 2016) \\
Xianghe & $5.39 \mu \mathrm{g} \mathrm{m}^{-3}$ & $2013-2014$ & (Ran et al., 2016) \\
Beijing & $4.3 \mu \mathrm{g} \mathrm{m}^{-3}$ & $2005-2013$ & (Chen et al., 2016) \\
Beijing & $3.67 \mu \mathrm{g} \mathrm{m}^{-3}$ & $2010-2014$ & (Liu et al., 2016) \\
Hefei & $3.5 \mu \mathrm{g} \mathrm{m}^{-3}$ & $2012-2013$ & (Zhang et al., 2015b) \\
Nanjing & $5.3 \mu \mathrm{g} \mathrm{m}^{-3}$ & $2011-2014$ & (Li et al., 2015a) \\
Baoji & $2.9 \mu \mathrm{g} \mathrm{m}^{-3}$ & 2015 & (Zhou et al., 2018) \\
\hline
\end{tabular}

such as Beijing, Nanjing, and Shanghai, BC concentrations in Xuzhou are relatively low considering annual average. Xuzhou is located in the eastern part of North China Plain, and is an important transportation center and regional economic center bordering two large agglomerations: the Yangtze River Delta city cluster in the south and BeijingTianjin-Hebei city cluster in the north. Due to the influences of summer and winter monsoon, air quality in Xuzhou is easily affected by these two agglomerations.

For $\mathrm{PM}_{1.0}, \mathrm{PM}_{2.5}$, and $\mathrm{PM}_{10}$, only 514 effective daily measurements were obtained. The average mass concentrations of $\mathrm{PM}_{10}, \mathrm{PM}_{2.5}$, and $\mathrm{PM}_{1.0}$ were $75.8 \mu \mathrm{g} \mathrm{m}^{-3}$ (17.5-273.33 $\left.\mu \mathrm{g} \mathrm{m}^{-3}\right), 61.8 \mu \mathrm{g} \mathrm{m}^{-3}\left(9.1-254.0 \mu \mathrm{g} \mathrm{m}^{-3}\right)$, and $56.6 \mu \mathrm{g} \mathrm{m}^{-3}\left(5.8-232.5 \mu \mathrm{g} \mathrm{m}^{-3}\right)$, respectively. During this period, $\mathrm{BC}$ accounted for $3.38 \%(0.09-9.68 \%)$ of $\mathrm{PM}_{10}$, $4.28 \%(0.1-13.9 \%)$ of $\mathrm{PM}_{2.5}$ and $4.78 \%(0.1-16.5 \%)$ of $\mathrm{PM}_{1.0}$, on average. Extremely high daily PM mainly occurred in late 2014 and early 2015 . This could be attributed to the strict environmental law enforcements in the autumn and winter seasons in northern China to ensure air quality.

Fig. 3 shows the monthly and seasonal variations of BC mass concentrations from May 2014 to July 2016 in Xuzhou. Only months with at least 15 effective daily values were selected to calculate the monthly average concentrations due to the consideration of representativeness and statistical meaning. Therefore, monthly mean data for 6 months were missing: December 2014, January 2015, November 2015, December 2015, January 2016, and May 2016. For the intra-annual aspect, the spring and winter months had higher $\mathrm{BC}$ concentrations, while the summer and autumn had lower BC concentrations. In 2014, BC concentrations in the autumn were lowest, while in 2015, those in the summer were lowest. Typically, winter months have the highest $\mathrm{BC}$ concentrations. Furthermore, it should be noted that, although the autumn and winter months had higher $\mathrm{BC}$ concentrations, they also had larger value ranges, with both extremely high values and extremely low values. The meteorological dispersion conditions may be the major reason for the large differences. The cold high pressure frequently controlled the northern China region, bringing stagnant weather conditions, which is unfavorable for the dispersion of atmospheric pollutants. When stagnant weather conditions occurred, $\mathrm{BC}$ concentrations tended to be high. On the other hand, cold waves with heavy wind facilitated pollution diffusion, making $\mathrm{BC}$ concentrations very low at these time. Most summer and autumn months have average $\mathrm{BC}$ concentrations of less than $2 \mu \mathrm{g} \mathrm{m}^{-3}$, while winter and spring months have $\mathrm{BC}$ concentrations of more than $2 \mu \mathrm{g} \mathrm{m}^{-3}$.

In 2012, the Ministry of Environmental Protection of China released the new version of National Ambient Air Quality Standards (NAAQS-2012, GB3095-2012), requesting real-time monitoring and online release of the $\mathrm{PM}_{2.5}, \mathrm{PM}_{10}$, $\mathrm{O}_{3}, \mathrm{SO}_{2}, \mathrm{NO}_{2}$, and $\mathrm{CO}$ concentrations. These real-time data have been utilized as important data sources to evaluate air quality of urban environments in China. Black carbon and $\mathrm{PM}_{1.0}$, however, were not included in the mandatory request of NAAQS-2012. Fig. 4 shows the monthly and seasonal variations of particulate matter mass concentrations from June 2014 to March 2016 in Xuzhou. The same data processing strategies as BC data were applied to particulate matter data. As a result, monthly data from July (2014), August (2014), September (2015), and June (2015) were excluded from the monthly average calculations. Except for June 2014, the summer months had lower particulate matter concentrations. Autumn 2014, winter 2014, and spring 2016 had relatively higher concentrations of particulate matter, with highest values in the winter months. From a monthly or seasonal view, average $\mathrm{PM}_{10}$ concentrations fell below $150 \mu \mathrm{g} \mathrm{m}^{-3}$, but only spring and summer months had $\mathrm{PM}_{10}$ concentrations of less than $70 \mu \mathrm{g} \mathrm{m}^{-3}$ considering the annual request of NAAQS-2012. For $\mathrm{PM}_{2.5}$ concentrations, 4 months (June 2014, November 2014, January 2015, and February 2015) had higher mass concentrations of more than $75 \mu \mathrm{g} \mathrm{m}^{-3}$, and all months had $\mathrm{PM}_{2.5}$ concentrations higher than $35 \mathrm{\mu g} \mathrm{m}^{-3}$ regarding the annual target of NAAQS-2012. Although there is no specific standard for $\mathrm{PM}_{1.0}$, mass concentrations of $\mathrm{PM}_{1.0}$ were found to be comparable to those of $\mathrm{PM}_{2.5}$, suggesting that $\mathrm{PM}_{1.0}$ may represent a large portion of the particulate matter. Overall, PM concentrations have been gradually decreased since the Chinese government has paid specific attention to the air pollution in northern China.

\section{Relationships between $B C$ and $P M_{1.0}, P M_{2.5}$, and $P M_{10}$}

The correlations between $\mathrm{PM}_{1.0}, \mathrm{PM}_{2.5}$, and $\mathrm{PM}_{10}$ are illustrated in Fig. 5. In this regression, we selected 5-minute average samples of particulate matter concentrations. In total 12,479 groups of valid 5-minute average samples were collected. For the correlation between $\mathrm{PM}_{1.0}$ and $\mathrm{PM}_{2.5}$, the R-square of the linear regression was 0.9964. For the $\mathrm{PM}_{1.0}-\mathrm{PM}_{10}$ and $\mathrm{PM}_{2.5}-\mathrm{PM}_{10}$ correlations, the corresponding R-squares were 0.9220 and 0.9462 , emphasizing the significance of correlations between $\mathrm{PM}_{1.0}, \mathrm{PM}_{2.5}$, and 

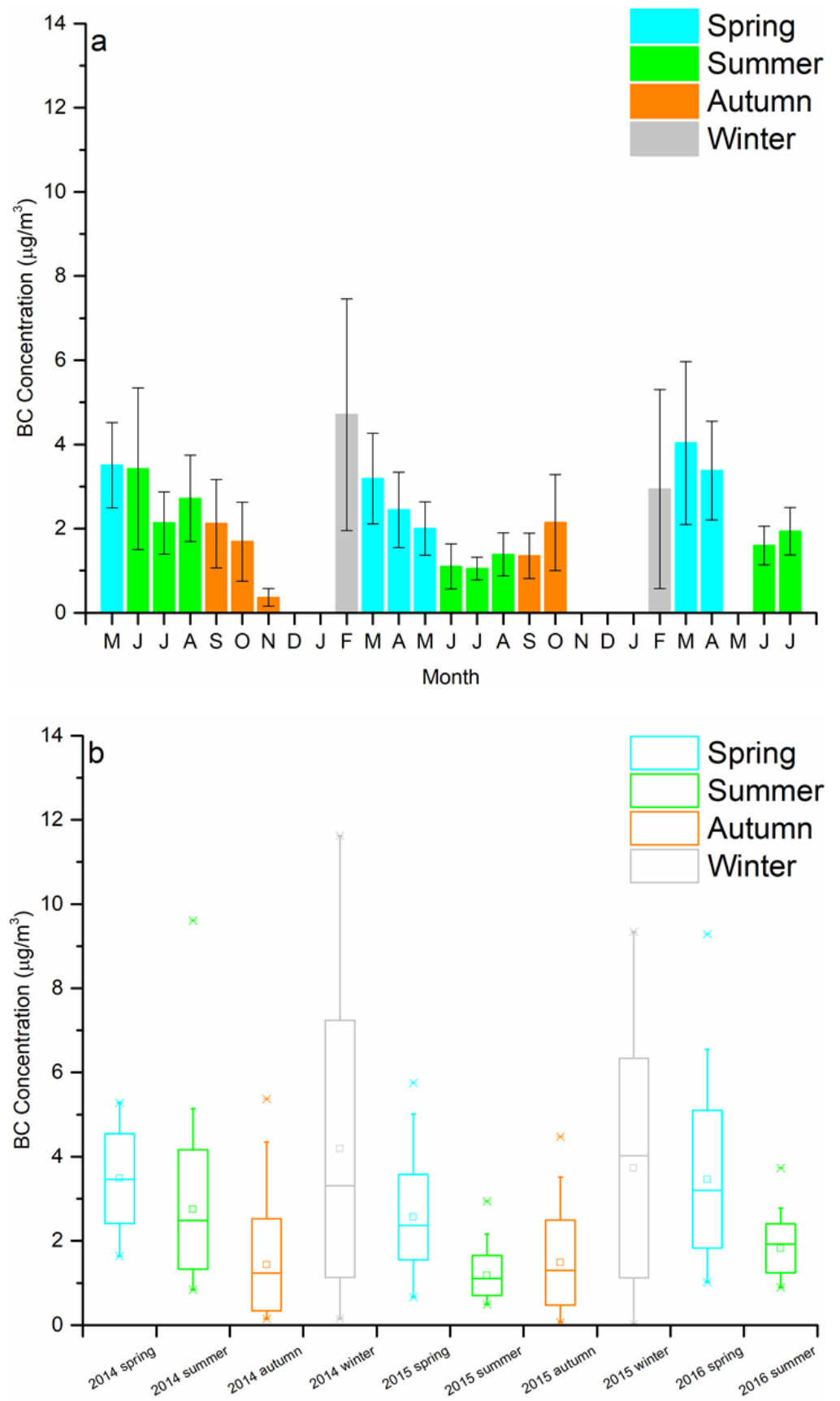

Fig. 3. (a) Monthly and (b) seasonal variations of BC mass concentration (in $\mu \mathrm{g} \mathrm{m}^{-3}$ ) in Xuzhou from May 2014 to July 2016. For Fig. 3(a), the bars represent monthly average concentrations and the whiskers are the standard deviations. For Fig. 3(b), lines in the boxes are the median mass concentrations of the seasons; the lower and upper lines of the boxes represent the $1^{\text {st }}$ and $3^{\text {rd }}$ quartiles. The lower and upper whiskers represent the $99 \%$ and $1 \%$ values. The stars above the top lines and below the bottom lines are the maximum and minimum values.

$\mathrm{PM}_{10}$ in Xuzhou. The statistical results demonstrated that $91.1 \%$ and $76.1 \%$ of the mass concentration of $\mathrm{PM}_{2.5}$ and $\mathrm{PM}_{10}$, respectively, was $\mathrm{PM}_{1.0}$ and $83.1 \%$ of the mass concentration of $\mathrm{PM}_{10}$ was $\mathrm{PM}_{2.5}$. This result reveals that ultrafine particles with diameters less than $1 \mu \mathrm{m}$ are the major components of particulate matter pollution in the urban atmospheric environment of Xuzhou. From the view of two-year measurements, it could be found that coarse mode aerosol $\left(\mathrm{PM}_{2.5-10}\right)$ only occupies $16.9 \%$ of total $\mathrm{PM}_{10}$.
Considering that coarse-mode aerosol pollution is highly associated with dust source aerosol possibly transported from desert or Gobi regions, while fine-mode aerosol is mainly local or regional source associated with anthropogenic emissions, our results suggested that despite some longrange transportation, the PM pollution in Xuzhou is mainly from local or neighboring regions' transportation (mainly the Yangtze River Delta city cluster and the BeijingTianjin-Hebei city cluster). 

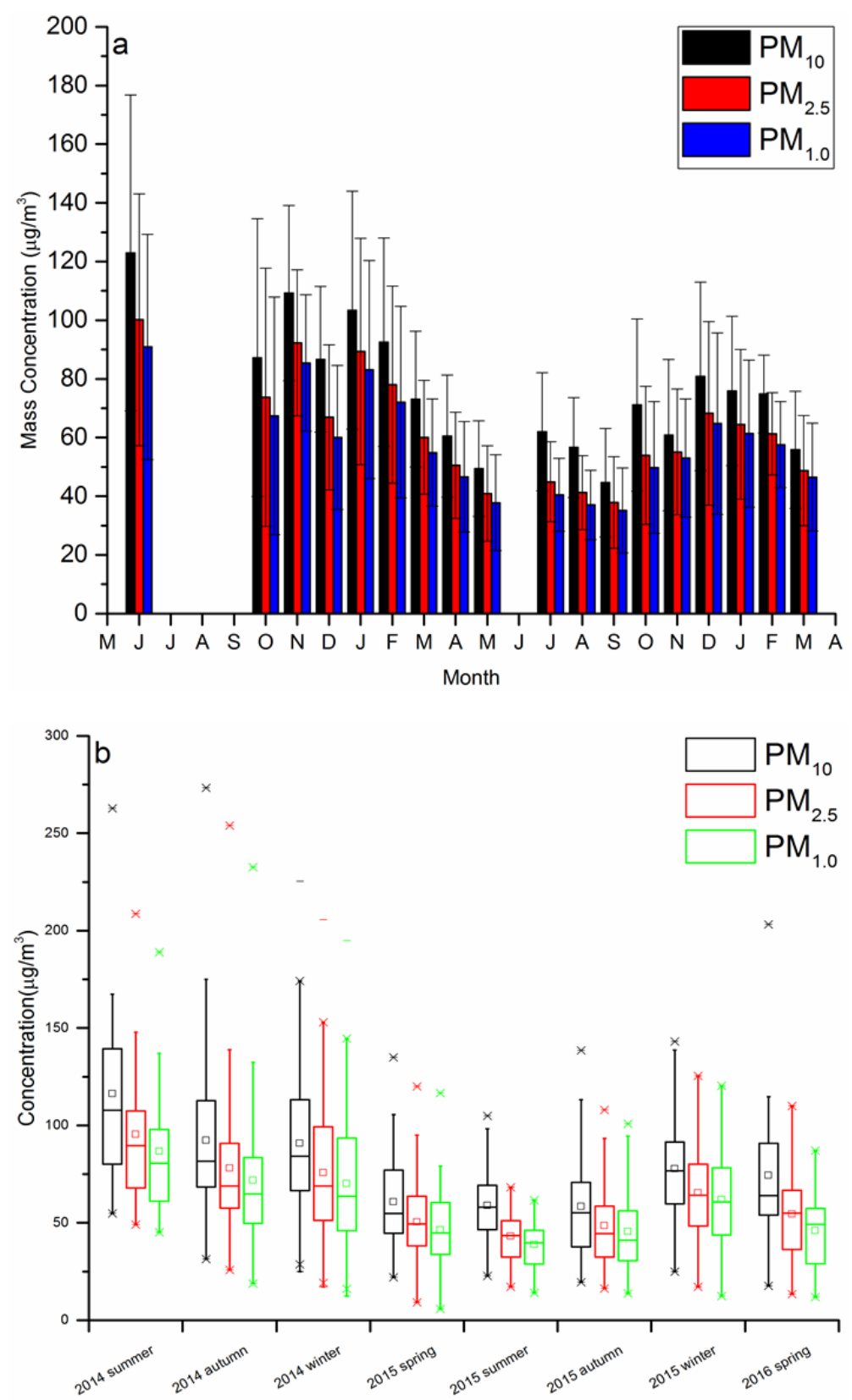

Fig. 4. Monthly (a) and seasonal (b) variations of particulate matter mass concentration (in $\mu \mathrm{g} \mathrm{m}^{-3}$ ) in Xuzhou from June 2014 to March 2016. For Fig. 4(a), the bars represent monthly average concentrations and the whiskers are the standard deviations. For Fig. 4(b), lines in the boxes are the median mass concentration of the seasons; the lower and upper lines of the boxes represent the $1^{\text {st }}$ and $3^{\text {rd }}$ quartiles. The lower and upper whiskers represent $99 \%$ and $1 \%$ values. The stars above the top lines and below the bottom lines are maximum and minimum values.

Black carbon monomer particles are usually regarded as fine particles with diameters ranging from $0.01-0.02 \mu \mathrm{m}$. Although black carbon particles only occupied a tiny part of particulate matters $\left(3.38 \%\right.$ in $\mathrm{PM}_{10}, 4.28 \%$ in $\mathrm{PM}_{2.5}$, and $4.78 \%$ in $\mathrm{PM}_{1.0}$ in Xuzhou), they could age with heavy coating, providing places for the formation of secondary aerosols. The ratios of $\mathrm{BC}$ in $\mathrm{PM}_{1.0}, \mathrm{PM}_{2.5}$, and $\mathrm{PM}_{10}$ are shown in Fig. 6, demonstrating that the ratios of $\mathrm{BC}$ in particulate matters were usually less than $10 \%$. The winter and spring months had higher $\mathrm{BC}$ ratios than the summer and autumn months. The increased combustion of coal during winter season for heating may be one important role for the higher $\mathrm{BC}$ ratios in northern Chinese regions (Ji et al., 2017; Zhou et al., 2018). Furthermore, unfavorable meteorological conditions during winter and spring months were also responsible for the accumulation of atmospheric pollutants (Han et al., 2015; Zhang et al., 2015a). Fig. 7 demonstrates the correlations between 5-minute average $\mathrm{BC}$ and particulate matter mass concentrations. In contrast to the relationships between $\mathrm{PM}_{1.0}, \mathrm{PM}_{2.5}$, and $\mathrm{PM}_{10}$, the correlations between $\mathrm{BC}$ and $\mathrm{PM}$ were not as high; the Rsquares of the linear regressions of $\mathrm{BC}-\mathrm{PM}_{1.0}, \mathrm{BC}-\mathrm{PM}_{2.5}$, 

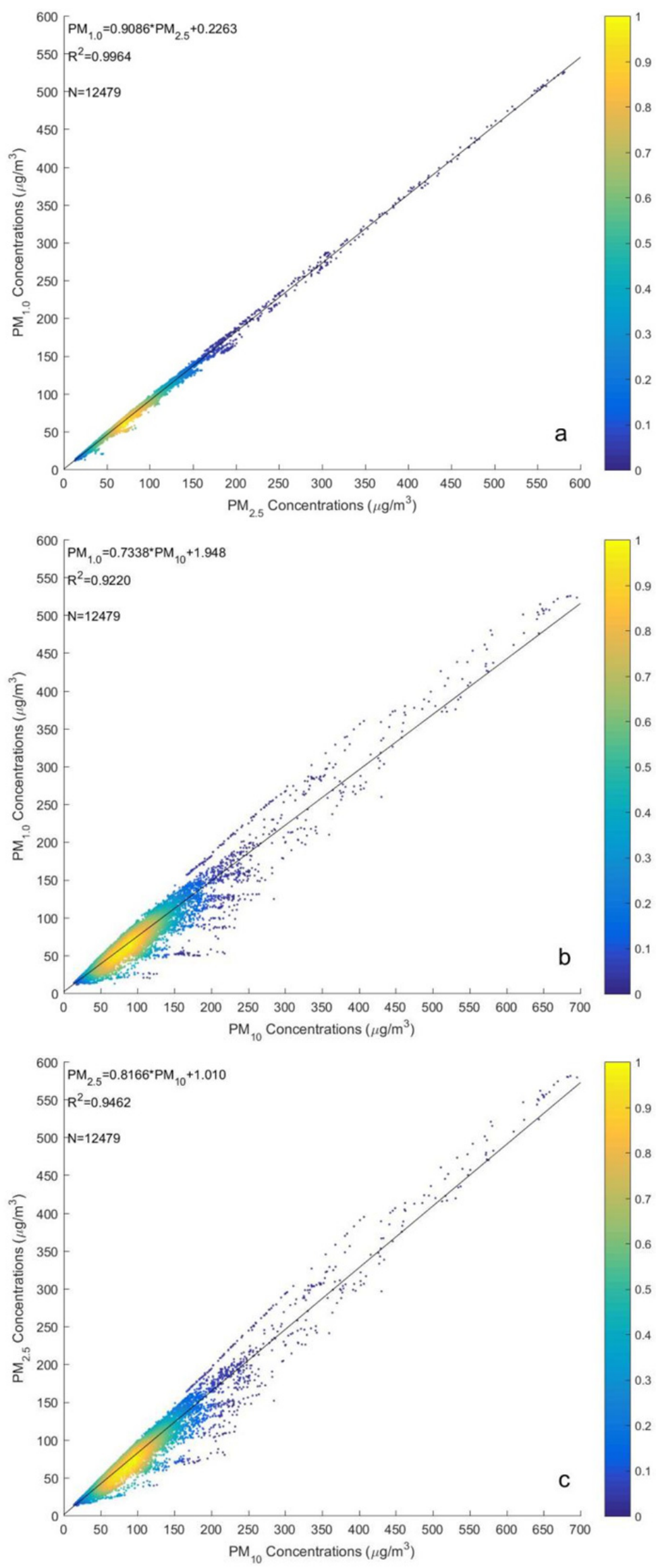

Fig. 5. Correlations between mass concentrations of (a) $\mathrm{PM}_{1.0}$ and $\mathrm{PM}_{2.5}$, (b) $\mathrm{PM}_{1.0}$ and $\mathrm{PM}_{10}$, and (c) $\mathrm{PM}_{2.5}$ and $\mathrm{PM}_{10}$. 


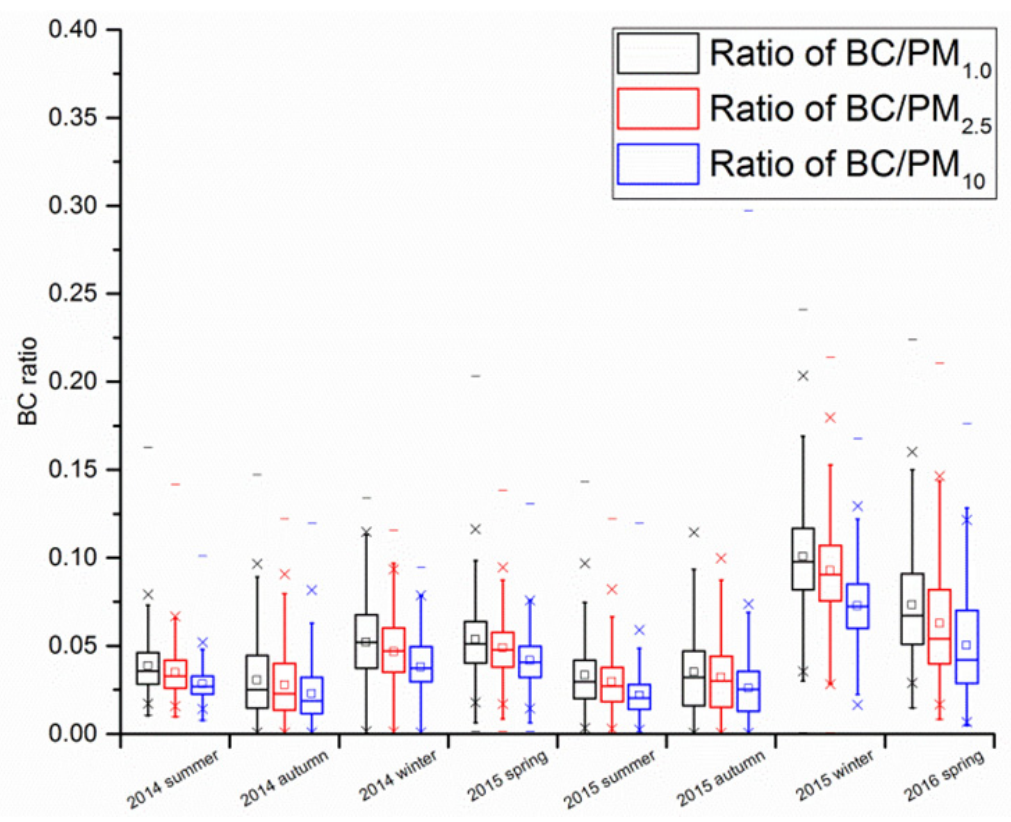

Fig. 6. $\mathrm{BC}$ mass ratio in particulate matter.

and $\mathrm{BC}-\mathrm{PM}_{10}$ were $0.6458,0.6622$, and 0.7214 , respectively. This suggests that besides $\mathrm{BC}$, other chemical components may contribute to the formation of PM. Nevertheless, the positive and high correlations between $\mathrm{BC}$ and $\mathrm{PM}$ indicate that $\mathrm{BC}$ play an important role in the formation of local aerosol pollution.

\section{Diurnal Variations of PM and BC}

The diurnal variations for $\mathrm{BC}$ and particulate matters are displayed in Fig. 8. In each subfigure, diurnal variations with annual data averaging and four seasons were demonstrated with different colors. Considering the eliminating effects of precipitation on $\mathrm{BC}$ and particulate matters, those data from days with precipitation on that day and/or the previous day were excluded to obtain diurnal variations without precipitation effects. Diurnal variations without a precipitation effect are demonstrated in each subfigure with dashed lines. Those data that include at least 16 hourly samples in each day were selected to ensure representativeness.

The variation shapes of $\mathrm{BC}$ and $\mathrm{PM}$ have similar tendencies, showing a bimodal shape: two peaks in the morning and evening rush hours and one valley in the afternoon. During different seasons, the peak times and valley times were different. The average annual morning peaks of $\mathrm{BC}$ in the spring and autumn were at approximately 07:00 local time. However, the peak of $\mathrm{BC}$ in the summer shifted 1 hour earlier to 06:00 local time, while in the winter, it shifted later to 08:00 local time. This may be caused by the longer daytime during summer months and shorter daytime during winter months. After the peak value in the morning, $\mathrm{BC}$ concentrations gradually decreased until 15:00-16:00 local time, forming the daily valley values. Then, $\mathrm{BC}$ concentrations increased again until 19:00-20:00, staying at a relatively high level throughout the night and forming the second peak value, which was lower than the first peak value in a day. There are two reasons for the first peak in the rush hour: First the air temperature at this time is low, which is unfavorable for this vertical dispersion of atmospheric pollutants; secondly, the busy traffic activities with high frequent traffic jams discharge large amounts of pollutants to boundary layer. After that time the temperature increases and the vehicles on road decrease. Then the atmospheric pollutants concentrations gradually decrease. The second rush hour, frequent human activities and lower temperature during evening help form the second pollution peak. The diurnal variations also suggested that winter and spring have higher $\mathrm{BC}$ concentrations, while summer and autumn have relatively lower BC concentrations. By excluding days affected by precipitation, the precipitation generally brought a decreasing effect on BC concentration of approximately $0.26 \mu \mathrm{g} \mathrm{m}^{-3}$ per hour, suggesting that from the view of long-term measurements, wet deposition may not be the major reason of the elimination of BC. The decreases mainly occurred in the morning and night, but not as much in the afternoon.

Diurnal variations of $\mathrm{PM}_{1.0}, \mathrm{PM}_{2.5}$, and $\mathrm{PM}_{10}$ showed a similar tendency of $\mathrm{BC}$ : two peaks in the morning and night, and one valley in the afternoon. For the annual average, the first peaks of $\mathrm{PM}_{1.0}, \mathrm{PM}_{2.5}$, and $\mathrm{PM}_{10}$ appeared at approximately 08:00 local time, ranging from 06:00 to 09:00 for different seasons. During the summer, the first peak occurred earlier at approximately 06:00, and the winter had a relatively late first peak. The valley value in the summer also appeared at a different time (18:00) than in other seasons (14:00-16:00). After the valley values, PM concentrations increased at the second peak of the day during evening and kept relatively high concentrations throughout the night. Excluding data from precipitation days, $\mathrm{PM}_{1.0}$ and $\mathrm{PM}_{2.5}$ were found to have little effect on diurnal variations in the summer and spring. However, excluding data from precipitation days sharply increased 

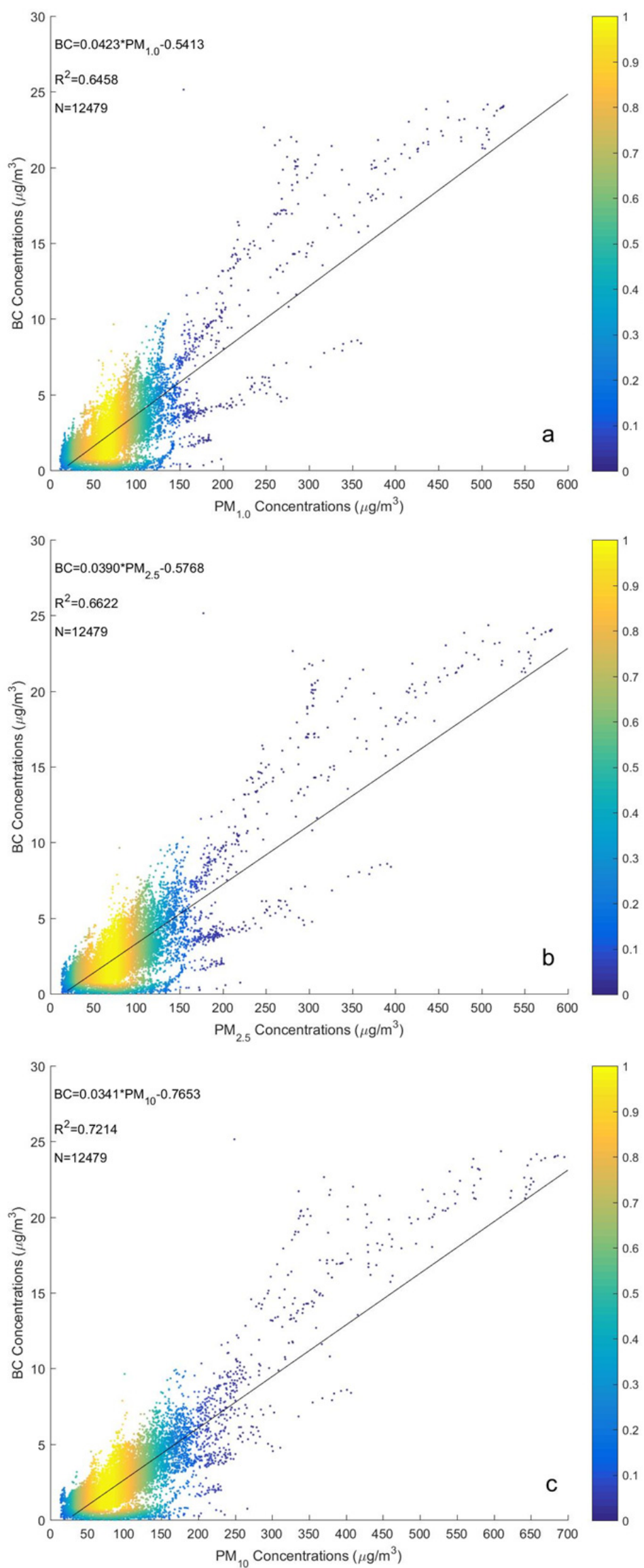

Fig. 7. Correlations between mass concentrations of (a) $B C$ and $\mathrm{PM}_{1.0}$, (b) $\mathrm{BC}$ and $\mathrm{PM}_{2.5}$, and (c) $\mathrm{BC}$ and $\mathrm{PM}_{10}$. 
the concentrations in autumn, especially during the two peak times. For winter, this decreased the $\mathrm{PM}_{1.0}$ and $\mathrm{PM}_{2.5}$ concentrations slightly, especially during valley times. For $\mathrm{PM}_{10}$, excluding data from precipitation days had an obvious contrasting effect, increasing the $\mathrm{PM}_{10}$ concentrations in the summer, autumn, and spring substantially but only slightly decreasing $\mathrm{PM}_{10}$ concentrations in the winter. These results are interesting; precipitation seems to have complex effects on the deposition and dispersion of atmospheric particles.
Back Trajectories and Potential Pollution Source Areas

To demonstrate the potential source of air pollutants, 48hour back trajectories with hourly mean $\mathrm{BC}$ concentrations higher than $5 \mu \mathrm{g} \mathrm{m}^{-3}$ were analyzed using the Hybrid Single Particle Lagrangian Integrated Trajectory (HYSPLIT) model developed by the Air Resources Laboratory (ARL). The HYSPLIT model was driven with gridded meteorological data (Global Data Assimilation System; GDAS1). Fig. 9 demonstrates the cluster results of 48-hour backward trajectories arriving at Xuzhou at $1500 \mathrm{~m}$ above
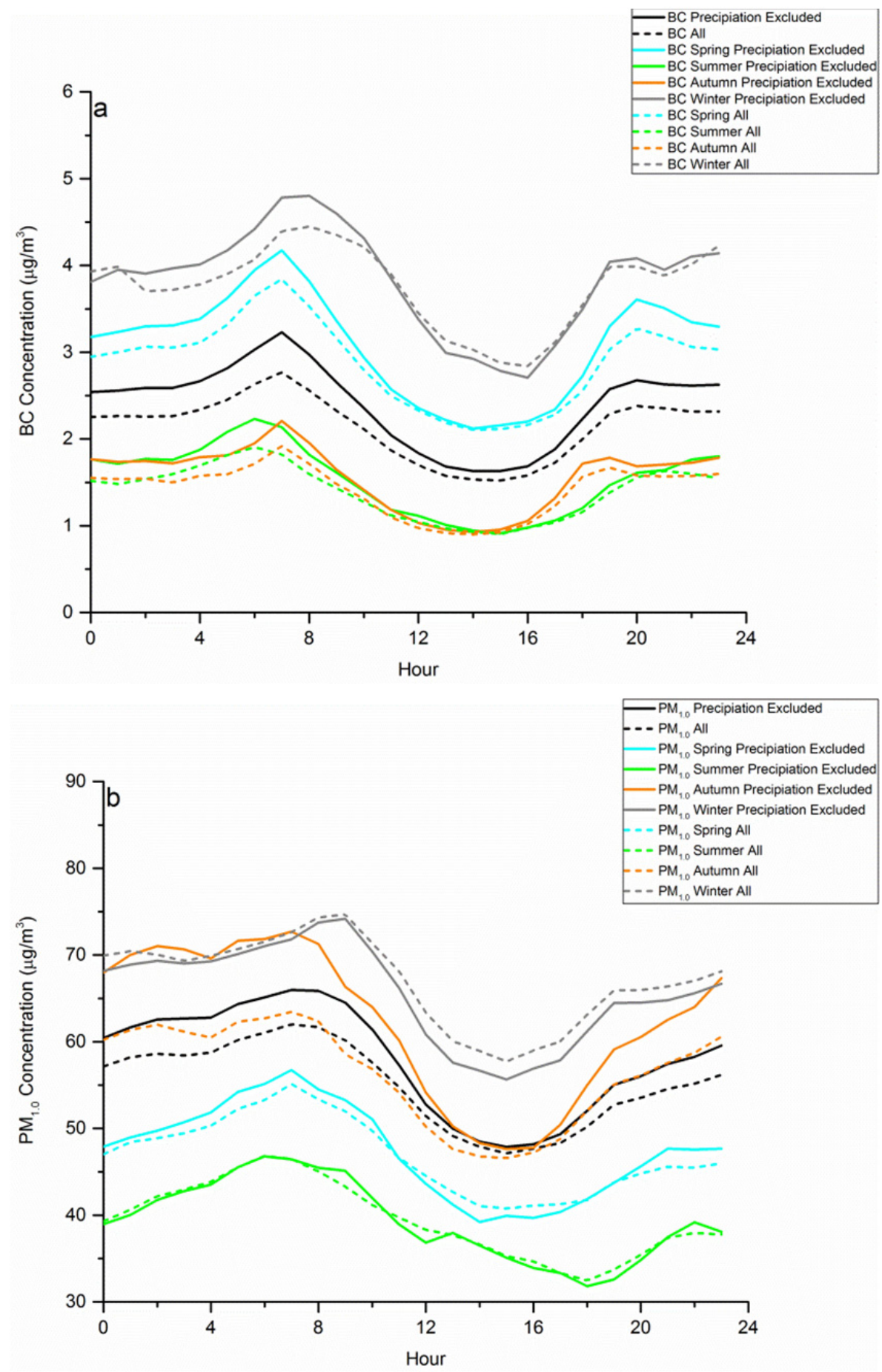

Fig. 8. Diurnal variations of mass concentrations of (a) $B C$, (b) $\mathrm{PM}_{1.0}$, (c) $\mathrm{PM}_{2.5}$, and (d) $\mathrm{PM}_{10}$. 

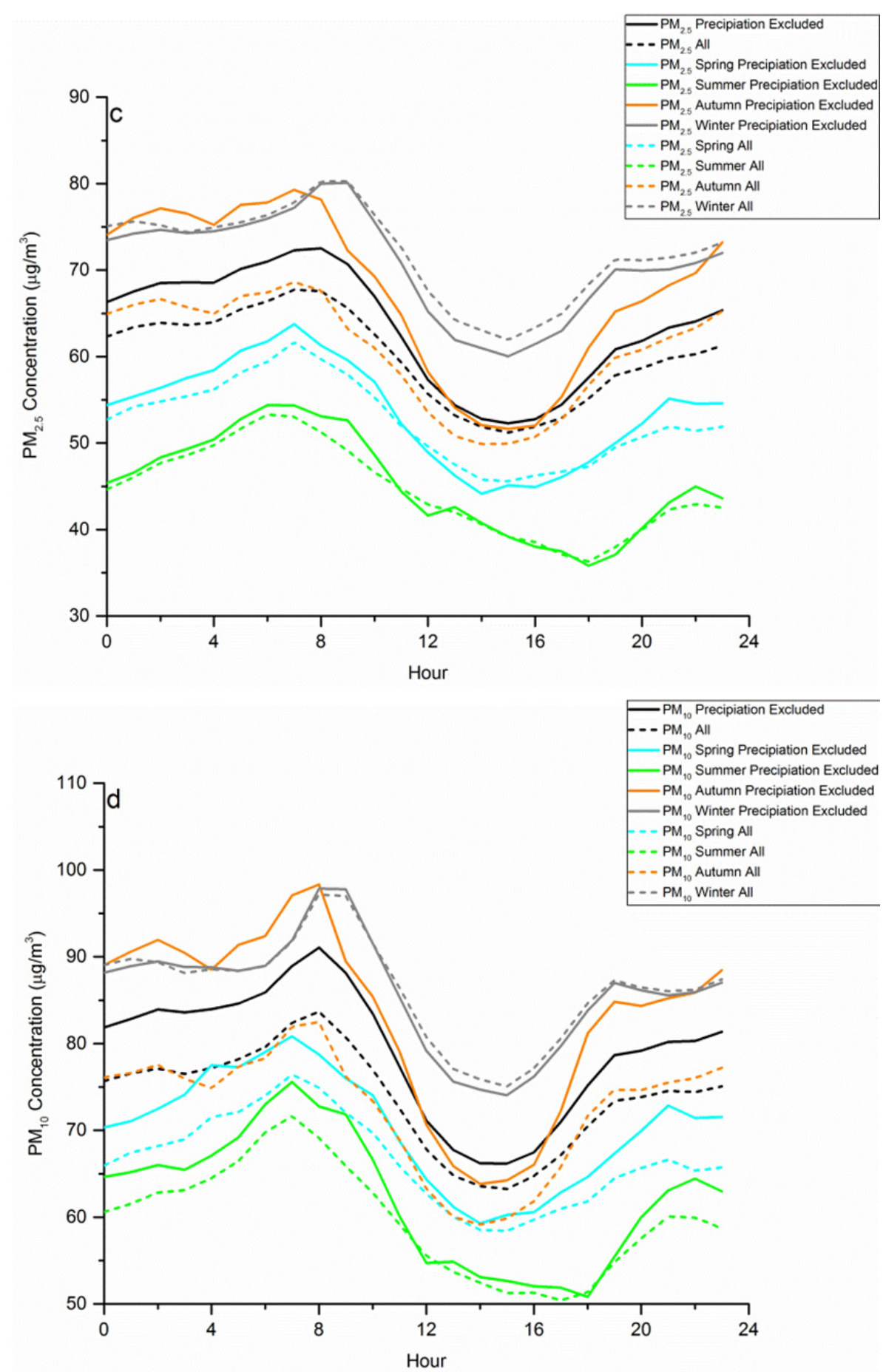

Fig. 8. (continued).

the ground at 1-hour intervals. The BC-polluted hours (with $\mathrm{BC}$ concentrations higher than $5 \mu \mathrm{g} \mathrm{m}^{-3}$, approximately the top $10 \%$ of all monitoring data) were selected for analysis. Fig. 9(a) demonstrates the clusters of BC-polluted hours year round. It was found that 3 cluster classes $(31.30 \%$, $12.27 \%$, and $22.95 \%$ ) originated from the northwest, 1 cluster class $(9.01 \%)$ from the nearby Shandong Province in the northeast direction, 1 cluster class $(11.47 \%)$ from the southwest and 1 cluster class $(13.00 \%)$ from nearby regions. The year-round cluster analysis suggests that approximately $66.52 \%$ of trajectories originated from the north and northwest. As Xuzhou is a city in eastern China severely affected by monsoons, the prevailing wind directions are different in different seasons. Figs. 9(b)-9(d) show the clusters of the BC-polluted hours in the four seasons. Figs. 9(b) and Fig. 9(e) are similar, with most BCpolluted hours originating from the northwest. Summer and autumn were much different from spring and winter. In the summer, as shown in Fig. 9(c), BC-polluted hours were mainly associated with nearby provinces' air mass 

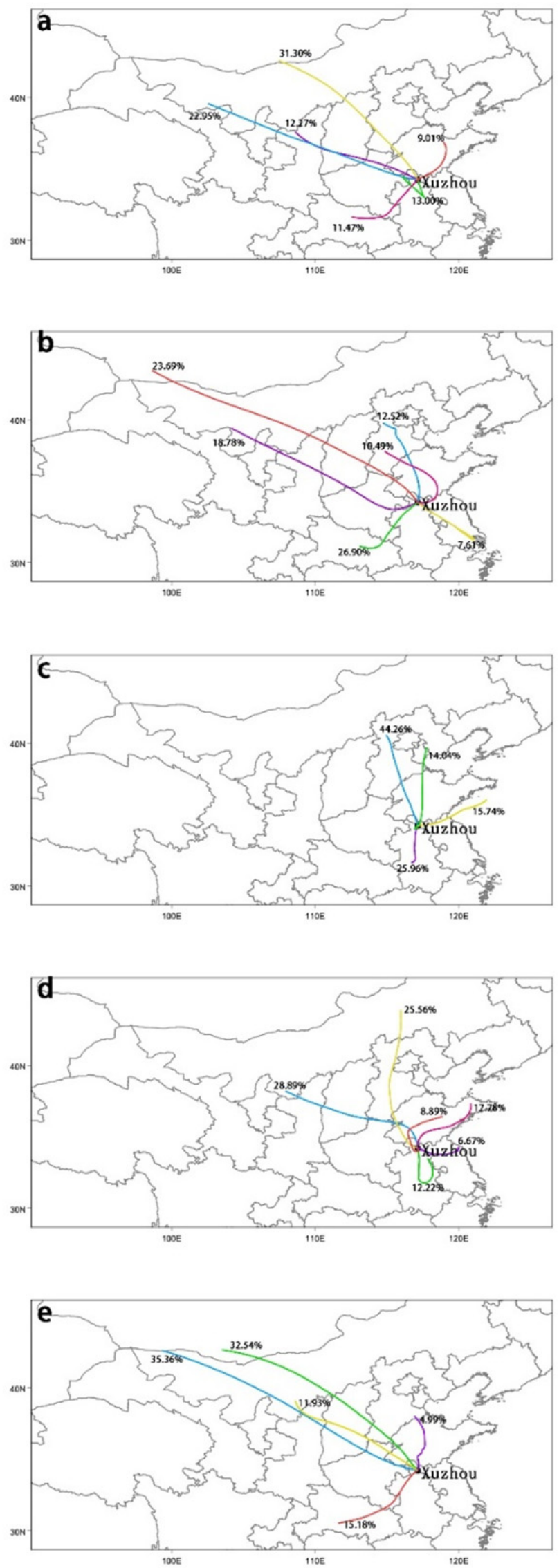

Fig. 9. Cluster analysis of 48-h backward air mass trajectories arriving at Xuzhou at $1500 \mathrm{~m}$ above the ground every hour the (a) entire year, (b) spring, (c) summer, (d) autumn, and (e) winter. 
transportation. In the autumn, approximately half of the BC-polluted hours were affected by northwest long-range air mass, and approximately half of the BC-polluted hours were associated with nearby air mass transportation, as shown in Fig. 9(d). In the spring and winter, monsoon makes the north wind prevailing, while in summer and autumn, south wind dominates. These trajectories clearly identified the three potential sources: The first is the Beijing-Tianjin-Hebei city cluster, second is the Yangtze River Delta city cluster in the southeast, the third is from central China, in the southeast.

The potential source contribution function (PSCF) model (Zong et al., 2018) was used to further explore the potential source regions that affected the $\mathrm{BC}$ concentrations in Xuzhou. The PSCF value in the $i j$ th cell could be defined as $\mathrm{PSCF}_{i j}=m_{i j} / n_{i j} \cdot m_{i j}$ is the number of endpoints that fall within the $i j$ th cell with $\mathrm{BC}$ concentrations higher than the criterion of $5 \mu \mathrm{g} \mathrm{m}^{-3} \cdot n_{i j}$ is the total number of endpoints that fall in the $i j$ th cell. As the PSCF value is a kind of conditional possibility, when the time the air flow stays in the cell is too short, the uncertainty of the PSCF value will increase. To reduce such uncertainty, an arbitrary weight function $W_{i j}$ is used to better reflect uncertainty in each cell when the $n_{i j}$ in the $i j$ th cell is less than approximately 3 times the average value of the end points in each cell. Here, $W_{i j}$ is defined as (Polissar et al., 2001):

$$
W_{i j}=\left\{\begin{array}{l}
1.0,80<n_{i j} \\
0.7,20<n_{i j} \leq 80 \\
0.42,10<n_{i j} \leq 20 \\
0.05, n_{i j} \leq 10
\end{array}\right.
$$

Fig. 10 shows the PSCF map produced by the hourly contribution data with the $10^{\text {th }}$ percentile cut $\left(5 \mu \mathrm{g} \mathrm{m}^{-3}\right)$ of the entire year (Fig. 10(a0), spring (Fig. 10(b)), summer (Fig. 10(c)), autumn (Fig. 10(d)) and winter (Fig. 10(e)). The region was divided into an array of $0.25^{\circ} \times 0.25^{\circ}$ grid cells. From the year-round view, central and northwestern China, including the western Shandong Province, southern Hebei Province, northern Henan Province, southern Shanxi Province, northern Shaanxi Province, and western Inner Mongolia are all medium potential regions for $\mathrm{BC}$ in Xuzhou. In the spring, central China west of Xuzhou was the potential BC source for Xuzhou. In the summer and autumn, BC-polluted episodes were less frequent than in the spring and winter, and nearby provinces were the potential sources for Xuzhou. In winter months, the cases were much more different and complex. Different from the previous three seasons, in the winter, the central provinces became high-potential BC sources for Xuzhou, suggesting high $\mathrm{BC}$ emissions in the winter in these regions.

\section{DISCUSSION}

Black carbon aerosol has been identified as an important factor that is responsible for the deterioration of air quality in many urban cities as it is an indicator of primary emissions. Many cities in China have reported BC measurements:
Beijing (annual average concentration: $3.67-4.36 \mu \mathrm{g} \mathrm{m}^{-3}$; Chen et al., 2016; Liu et al., 2016), Heifei (annual average concentration: $3.5 \mathrm{\mu g} \mathrm{m}^{-3}$; Zhang et al., 2015b), and Nanjing (annual average concentration: $5.3 \mu \mathrm{g} \mathrm{m}^{-3}$ ). Most research has demonstrated that winter months have relatively higher concentrations, mainly due to more emissions during seasons that require heating. For Beijing, BC concentrations on hazy days were 1-2 times higher than those on non-hazy days, while the ratios of $\mathrm{BC}$ to $\mathrm{PM}_{2.5}$ were lower on hazy days (Liu et al., 2016). These results suggested that, although BC plays an important role in the formation of particulate matter in the megacity of Beijing, air mass transportation and secondary aerosol could not be neglected. Meteorological conditions also affect the formation and dispersion of $\mathrm{BC}$ and particulate matter. In Beijing, the $\mathrm{BC}$ and $\mathrm{PM}_{2.5}$ concentrations were found to be negatively correlated with wind speed but not significantly correlated with precipitation (Liu et al., 2016). Another nine-yearlong research project found that south-to-east winds with low wind speed were generally correlated with poor visibility and high $\mathrm{BC}$ concentrations (Chen et al., 2016). Similar studies in Nanjing (eastern China) and Wuhan (central China) have found that poor dispersion weather conditions were responsible for the occurrences of high BC concentrations (Gong et al., 2015; Li et al., 2015a). However, another year-round measurement in Hefei demonstrated that BC was mainly from local emissions with poor correlation with wind speeds (Zhang et al., 2015b). Aside from meteorological factors, traffic flows could affect BC concentrations (Cheng et al., 2015b). Additionally, BC concentrations were lower during important activities, such as the World Expo, accompanied by temporary government mitigation measures, such as restrictions on vehicles and industry production (Feng et al., 2014). Overall, local emissions, dispersion conditions, regional transportations, and temporal control measures all play important roles in $\mathrm{BC}$ concentration variations.

For Xuzhou, the two neighboring regions of the Yangtze River Delta and Beijing-Tianjin-Hebei (shown in Fig. 1) are seriously polluted; high $\mathrm{BC} / \mathrm{PM}$ concentrations were frequently correlated with both south winds (from the Yangtze River Delta) and north winds (from Beijing-TianjinHebei and Henan Province). The PSCF maps demonstrated that central Chinese provinces, including Hebei, Shandong, Henan, Shanxi, Shaanxi, and Anhui, are all possible BC sources for Xuzhou. Besides this transportation, it is highly possible that local emissions may also affect the pollution level in Xuzhou. In 2012, the annual coal consumption in Xuzhou was about $4.86 \times 10^{7} \mathrm{t}$ (Liu, 2016) and the number of vehicles reached 1.44 million by the end of 2017 .

Annual emissions of $\mathrm{PM}_{2.5}$ and $\mathrm{PM}_{10}$ could reach $4.19 \times$ $10^{4} \mathrm{t}$ and $2.68 \times 10^{4} \mathrm{t}$, mainly caused by thermal powers, cement plants and other foundry industries. The winter heating period (approximately from November 15 to March 15) with large amount of extra coal combustion also contribute the booming level of air pollution in these months. As a fast developing regional economic center, $\mathrm{BC}$ as well as PM pollution level are affected by both neighboring agglomerations and local emissions. 

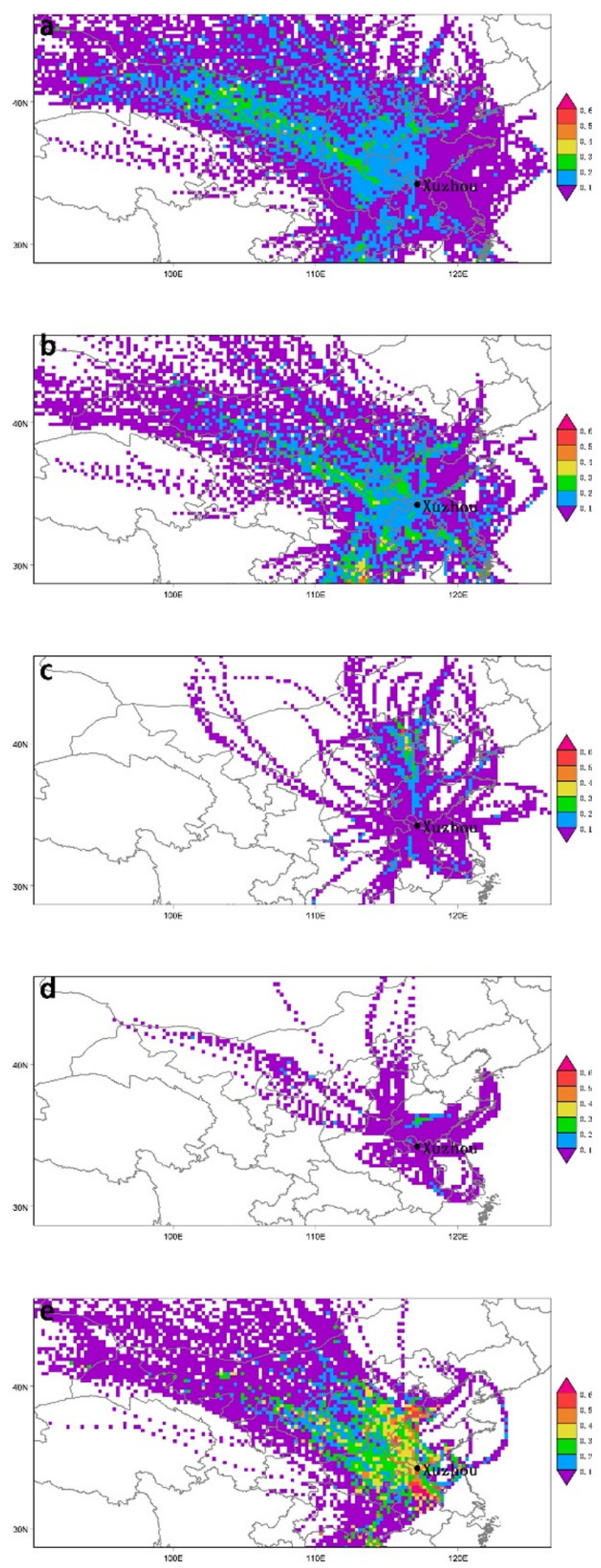

Fig. 10. PSCF maps of the BC of Xuzhou for the (a) entire year, (b) spring, (c) summer, (d) autumn, and (e) winter. Only back trajectories with hourly $\mathrm{BC}$ concentration larger than $5 \mu \mathrm{g} \mathrm{m}^{-3}$ were included. 


\section{CONCLUSIONS}

Black carbon aerosol is a significant component in particulate matters $\left(\mathrm{PM}_{1.0}, \mathrm{PM}_{2.5}\right.$, and $\left.\mathrm{PM}_{10}\right)$ in the atmospheric environment, which is regarded as the major cause of air quality deterioration in the regions of northern China, and plays an important role, despite its relatively low concentrations (approximately $2.4 \mu \mathrm{g} \mathrm{m}^{-3}$ in Xuzhou), in absorbing incident solar energy and acting as a hotspot for the formation of secondary aerosols. Furthermore, black carbon in the atmosphere suppresses the evolution of the boundary layer, affecting the dispersion of air pollution.

In this paper, we analyzed a two-year field measurement of $\mathrm{BC}$ and particulate matter in Xuzhou, an industrialized city in central China and the economic center of the Huaihai Economic Zone. Xuzhou is located between two severely polluted regions in China: the Yangtze River Delta region and the Beijing-Tianjin-Hebei region. Therefore, Xuzhou is easily affected by pollution transported from neighboring regions in addition to its own local emissions. We found that the annual average concentrations of $\mathrm{BC}, \mathrm{PM}_{1.0}, \mathrm{PM}_{2.5}$, and $\mathrm{PM}_{10}$ in Xuzhou were $2.4 \mu \mathrm{g} \mathrm{m}^{-3}, 56.6 \mu \mathrm{g} \mathrm{m}^{-3}, 61.8 \mu \mathrm{g} \mathrm{m}^{-3}$, and $75.8 \mu \mathrm{g} \mathrm{m}^{-3}$, respectively. BC concentrations in winter and spring were higher than in summer and autumn, whereas PM concentrations were higher in winter and autumn. The diurnal variations in the $\mathrm{BC}$ and the $\mathrm{PM}$ were similar: two peaks during the rush hours in the morning and in the evening and one valley in the afternoon.

Backward trajectory analysis (using the HYSPLIT model) revealed that the highest $\mathrm{BC}$ concentrations were associated with north or northwest winds, suggesting that the neighboring provinces may be significant sources of $\mathrm{BC}$ pollution in Xuzhou. The potential source contribution function (PSCF) model demonstrated that the $\mathrm{BC}$ source regions varied by season, i.e., the central Chinese provinces likely contributed emissions during winter and spring but were a much less likely source region during summer and autumn. Nevertheless, these results suggest that during winter and spring, $\mathrm{BC}$ emissions in central China are very high and require further control measures.

\section{ACKNOWLEDGMENTS}

This work was supported by the National Key Research and Development Program of China (2017YFC0210102), National Natural Science Foundation of China (Grant No. 41701391), and the Fundamental Research Funds for the Central Universities (Grant No. 2014QD02).

\section{REFERENCES}

Batterman, S., Xu, L.Z., Chen, F., Chen, F. and Zhong, X.F. (2016). Characteristics of $\mathrm{PM}_{2.5}$ concentrations across Beijing during 2013-2015. Atmos. Environ. 145: 104-114.

Bond, T.C., Doherty, S.J., Fahey, D.W., Forster, P.M., Berntsen, T., DeAngelo, B.J., Flanner, M.G., Ghan, S., Karcher, B., Koch, D., Kinne, S., Kondo, Y., Quinn, P.K., Sarofim, M.C., Schultz, M.G., Schulz, M.,
Venkataraman, C., Zhang, H., Zhang, S., Bellouin, N., Guttikunda, S.K., Hopke, P.K., Jacobson, M.Z., Kaiser, J.W., Klimont, Z., Lohmann, U., Schwarz, J.P., Shindell, D., Storelvmo, T., Warren, S.G. and Zender, C.S. (2013). Bounding the role of black carbon in the climate system: A scientific assessment. J. Geophys. Res. 118: 53805552.

Chai, F., Gao, J., Chen, Z., Wang, S., Zhang, Y., Zhang, J., Zhang, H., Yun, Y. and Ren, C. (2014). Spatial and temporal variation of particulate matter and gaseous pollutants in 26 cities in China. J. Environ. Sci. 26: 7582.

Chameides, W.L. and Bergin, M. (2002). Climate change Soot takes center stage. Science 297: 2214-2215.

Che, H.Z., Qi, B., Zhao, H.J., Xia, X.G., Eck, T.F., Goloub, P., Dubovik, O., Estelles, V., Cuevas-Agullo, E., Blarel, L., Wu, Y.F., Zhu, J., Du, R.G., Wang, Y.Q., Wang, H., Gui, K., Yu, J., Zheng, Y., Sun, T.Z., Chen, Q.L., Shi, G.Y. and Zhang, X.Y. (2018). Aerosol optical properties and direct radiative forcing based on measurements from the China Aerosol Remote Sensing Network (CARSNET) in eastern China. Atmos. Chem. Phys. 18: 405-425.

Chen, Y., Schleicher, N., Fricker, M., Cen, K., Liu, X.L., Kaminski, U., Yu, Y., Wu, X.F. and Norra, S. (2016). Long-term variation of black carbon and $\mathrm{PM}_{2.5}$ in Beijing, China with respect to meteorological conditions and governmental measures. Environ. Pollut. 212: 269278.

Cheng, T.H., Wu, Y., Gu, X.F. and Chen, H. (2015a). Effects of mixing states on the multiple-scattering properties of soot aerosols. Opt. Express 23: 1080810821.

Cheng, Y., Lee, S.C., Gao, Y., Cui, L., Deng, W.J., Cao, J.J., Shen, Z.X. and Sun, J. (2015b). Real-time measurements of $\mathrm{PM}_{2.5}, \mathrm{PM}_{10-2.5}$, and $\mathrm{BC}$ in an urban street canyon. Particuology 20: 134-140.

Ding, A.J., Huang, X., Nie, W., Sun, J.N., Kerminen, V.M., Petaja, T., Su, H., Cheng, Y.F., Yang, X.Q., Wang, M.H., Chi, X.G., Wang, J.P., Virkkula, A., Guo, W.D., Yuan, J., Wang, S.Y., Zhang, R.J., Wu, Y.F., Song, Y., Zhu, T., Zilitinkevich, S., Kulmala, M. and Fu, C.B. (2016). Enhanced haze pollution by black carbon in megacities in China. Geophys. Res. Lett. 43: 2873-2879.

Feng, J., Zhong, M., Xu, B., Du, Y., Wu, M., Wang, H. and Chen, C. (2014). Concentrations, seasonal and diurnal variations of black carbon in $\mathrm{PM}_{2.5}$ in Shanghai, China. Atmos. Res. 147: 1-9.

Fontes, T., Li, P., Barros, N. and Zhao, P. (2017). Trends of $\mathrm{PM}_{2.5}$ concentrations in China: A long term approach. J. Environ. Manage. 196: 719-732.

Gong, W., Zhang, T., Zhu, Z., Ma, Y., Ma, X. and Wang, W. (2015). Characteristics of $\mathrm{PM}_{1.0}, \mathrm{PM}_{2.5}$, and $\mathrm{PM}_{10}$, and their relation to black carbon in Wuhan, Central China. Atmosphere 6: 1377-1387.

Guo, J., Liu, H., Li, Z., Rosenfeld, D., Jiang, M., Xu, W., Jiang, J.H., He, J., Chen, D., Min, M. and Zhai, P. (2018). Aerosol-induced changes in the vertical structure of 
precipitation: A perspective of trmm precipitation radar. Atmos. Chem. Phys. 18: 13329-13343.

Han, L.J., Zhou, W.Q., Li, W.F., Meshesha, D.T., Li, L. and Zheng, M.Q. (2015). Meteorological and urban landscape factors on severe air pollution in Beijing. $J$. Air Waste Manage. Assoc. 65: 782-787.

Hansen, J. and Nazarenko, L. (2004). Soot climate forcing via snow and ice albedos. Proc. Natl. Acad. Sci. U.S.A. 101: 423-428.

Jacobson, M.Z. (2001). Strong radiative heating due to the mixing state of black carbon in atmospheric aerosols. Nature 409: 695-697.

Janssen, N.A.H., Fischer, P., Marra, M., Ameling, C. and Cassee, F.R. (2013). Short-term effects of $\mathrm{PM}_{2.5}, \mathrm{PM}_{10}$ and $\mathrm{PM}_{2.5-10}$ on daily mortality in the netherlands. Sci. Total Environ. 463: 20-26.

Ji, D., Li, L., Pang, B., Xue, P., Wang, L., Wu, Y., Zhang, H. and Wang, Y. (2017). Characterization of black carbon in an urban-rural fringe area of Beijing. Environ. Pollut. 223: 524-534.

Knobelspiesse, K., Cairns, B., Redemann, J., Bergstrom, R.W. and Stohl, A. (2011). Simultaneous retrieval of aerosol and cloud properties during the MILAGRO field campaign. Atmos. Chem. Phys. 11: 6245-6263.

Koch, D. and Del Genio, A.D. (2010). Black carbon semidirect effects on cloud cover: Review and synthesis. Atmos. Chem. Phys. 10: 7685-7696.

Kovilakam, M. and Mahajan, S. (2015). Black carbon aerosol-induced Northern Hemisphere tropical expansion. Geophys. Res. Lett. 42: 4964-4972.

Kuang, Y., Zhao, C.S., Tao, J.C. and Ma, N. (2015). Diurnal variations of aerosol optical properties in the North China Plain and their influences on the estimates of direct aerosol radiative effect. Atmos. Chem. Phys. 15: 5761-5772.

Li, B., Zhang, J., Zhao, Y., Yuan, S., Zhao, Q., Shen, G. and $\mathrm{Wu}, \mathrm{H}$. (2015a). Seasonal variation of urban carbonaceous aerosols in a typical city Nanjing in Yangtze River Delta, China. Atmos. Environ. 106: 223231.

Li, J.D., Mao, J.Y. and Wang, W.C. (2015b). Anthropogenic Eastern Asian radiative forcing due to sulfate and black carbon aerosols and their time evolution estimated by an AGCM. Chinese J. Geophys. 58: 1103-1120. (in Chinese)

Li, R., Cui, L., Li, J., Zhao, A., Fu, H., Wu, Y., Zhang, L., Kong, L. and Chen, J. (2017). Spatial and temporal variation of particulate matter and gaseous pollutants in China during 2014-2016. Atmos. Environ. 161: 235246.

Liu, Q., Ma, T., Olson, M.R., Liu, Y., Zhang, T., Wu, Y. and Schauer, J.J. (2016). Temporal variations of black carbon during haze and non-haze days in Beijing. Sci. Rep. 6: 33331.

Liu, Y. (2016). Emission inventory for air pollutants of points sources in Xuzhou, Beijing University of Forestry, China.

Peng, J.F., Hu, M., Guo, S., Du, Z.F., Zheng, J., Shang, D.J., Zamora, M.L., Zeng, L.M., Shao, M., Wu, Y.S.,
Zheng, J., Wang, Y., Glen, C.R., Collins, D.R., Molina, M.J. and Zhang, R.Y. (2016). Markedly enhanced absorption and direct radiative forcing of black carbon under polluted urban environments. Proc. Natl. Acad. Sci. U.S.A. 113: 4266-4271.

Polissar, A.V., Hopke, P.K. and Harris, J.M. (2001). Source regions for atmospheric aerosol measured at Barrow, Alaska. Environ. Sci. Technol. 35: 4214-4226.

Qin, K., Wu, L., Wong, M.S., Letu, H., Hu, M., Lang, H., Sheng, S., Teng, J., Xiao, X. and Yuan, L. (2016). Trans-boundary aerosol transport during a winter haze episode in China revealed by ground-based Lidar and CALIPSO satellite. Atmos. Environ. 141: 20-29.

Qin, K., Wang, L., Wu, L., Xu, J., Rao, L., Letu, H., Shi, T. and Wang, R. (2017). A campaign for investigating aerosol optical properties during winter hazes over Shijiazhuang, China. Atmos. Res. 198: 113-122.

Qin, K., Zou, J., Guo, J., Lu, M., Bilal, M., Zhang, K., Ma, F. and Zhang, Y. (2018). Estimating $\mathrm{PM}_{1}$ concentrations from MODIS over Yangtze River Delta of China during 2014-2017. Atmos. Environ. 195: 149-158.

Ran, L., Deng, Z.Z., Wang, P.C. and Xia, X.A. (2016). Black carbon and wavelength-dependent aerosol absorption in the North China Plain based on two-year aethalometer measurements. Atmos. Environ. 142: 132144.

Song, C.B., He, J.J., Wu, L., Jin, T.S., Chen, X., Li, R.P., Ren, P.P., Zhang, L. and Mao, H.J. (2017). Health burden attributable to ambient $\mathrm{PM}_{2.5}$ in China. Environ. Pollut. 223: 575-586.

Sun, T.Z., Che, H.Z., Qi, B., Wang, Y.Q., Dong, Y.S., Xia, X.G., Wang, H., Gui, K., Zheng, Y., Zhao, H.J., Ma, Q.L., Du, R.G. and Zhang, X.Y. (2018). Aerosol optical characteristics and their vertical distributions under enhanced haze pollution events: Effect of the regional transport of different aerosol types over Eastern China. Atmos. Chem. Phys. 18: 2949-2971.

Virkkula, A., Makela, T., Hillamo, R., Yli-Tuomi, T., Hirsikko, A., Hameri, K. and Koponen, I.K. (2007). A simple procedure for correcting loading effects of aethalometer data. J. Air Waste Manage. Assoc. 57: 1214-1222.

Wang, Y., Ying, Q., Hu, J. and Zhang, H. (2014). Spatial and temporal variations of six criteria air pollutants in 31 provincial capital cities in China during 2013-2014. Environ. Int. 73: 413-422.

Wang, F., Guo, Z., Lin, T. and Rose, N.L. (2016). Seasonal variation of carbonaceous pollutants in $\mathrm{PM}_{2.5}$ at an urban 'supersite' in Shanghai, China. Chemosphere 146: 238-244.

Wu, Y., Cheng, T.H., Zheng, L.J. and Chen, H. (2016). Black carbon radiative forcing at TOA decreased during aging. Sci. Rep. 6: 38592.

Xin, J.Y., Gong, C.S., Wang, S.G. and Wang, Y.S. (2016). Aerosol direct radiative forcing in desert and semi-desert regions of northwestern China. Atmos. Res. 171: 56-65.

Xu, Z., Wen, T., Li, X., Wang, J. and Wang, Y. (2015). Characteristics of carbonaceous aerosols in Beijing based on two-year observation. Atmos. Pollut. Res. 6: 
202-208.

Yang, S., Xu, B.Q., Cao, J.J., Zender, C.S. and Wang, M. (2015). Climate effect of black carbon aerosol in a Tibetan Plateau glacier. Atmos. Environ. 111: 71-78.

Zhang, H., Wang, Y., Hu, J., Ying, Q. and Hu, X.M. (2015a). Relationships between meteorological parameters and criteria air pollutants in three megacities in China. Environ. Res. 140: 242-254.

Zhang, R., Jing, J., Tao, J., Hsu, S.C., Wang, G., Cao, J., Lee, C.S.L., Zhu, L., Chen, Z., Zhao, Y. and Shen, Z. (2013). Chemical characterization and source apportionment of $\mathrm{PM}_{2.5}$ in Beijing: Seasonal perspective. Atmos. Chem. Phys. 13: 7053-7074.

Zhang, S.L., Ma, N., Kecorius, S., Wang, P.C., Hu, M., Wang, Z.B., Groess, J., Wu, Z.J. and Wiedensohler, A. (2016). Mixing state of atmospheric particles over the North China Plain. Atmos. Environ. 125: 152-164.
Zhang, X., Rao, R., Huang, Y., Mao, M., Berg, M.J. and Sun, W. (2015b). Black carbon aerosols in urban central China. J. Quant. Spectrosc. Radiat. Transfer 150: 3-11. Zhou, B.H., Wang, Q.Y., Zhou, Q., Zhang, Z.Q., Wang, G.H., Fang, N., Li, M.J. and Cao, J.J. (2018). Seasonal characteristics of black carbon aerosol and its potential source regions in Baoji, China. Aerosol Air Qual. Res. 18: 397-406.

Zong, Z., Wang, X., Tian, C., Chen, Y., Fu, S., Qu, L., Ji, L., Li, J. and Zhang, G. (2018). PMF and PSCF based source apportionment of $\mathrm{PM}_{2.5}$ at a regional background site in North China. Atmos. Res. 203: 207-215.

Received for review, August 17, 2018 Revised, November 20, 2018 Accepted, December 1, 2018 